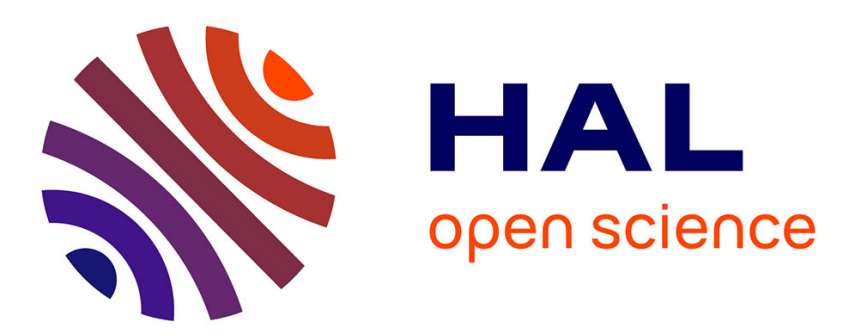

\title{
A glimpse of Dubai in Khartoum and Nouakchott, Prestige Urban Projects on the Margins of the Arab World
}

\author{
Armelle Choplin, Alice Franck
}

\section{> To cite this version:}

Armelle Choplin, Alice Franck. A glimpse of Dubai in Khartoum and Nouakchott, Prestige Urban Projects on the Margins of the Arab World. Built Environment, 2010, 36 (2), pp.64-77. halshs00547524

\section{HAL Id: halshs-00547524 \\ https://shs.hal.science/halshs-00547524}

Submitted on 3 Jan 2011

HAL is a multi-disciplinary open access archive for the deposit and dissemination of scientific research documents, whether they are published or not. The documents may come from teaching and research institutions in France or abroad, or from public or private research centers.
L'archive ouverte pluridisciplinaire HAL, est destinée au dépôt et à la diffusion de documents scientifiques de niveau recherche, publiés ou non, émanant des établissements d'enseignement et de recherche français ou étrangers, des laboratoires publics ou privés. 


\section{A GLIMPSE OF DUBAI IN KHARTOUM AND NOUAKCHOTT}

Prestige urban projects on the margins of the Arab world

Armelle Choplin, associate professor of geography, Paris-Est Marne-la-Vallée University, EA ACP / UMR PRODIG, armelle.choplin@univ-paris-est.ff

Alice Franck, associate professor of geography, Paris 1 Panthéon-Sorbonne University, UMR PRODIG, alice.franck@univ-paris1.fr

Most urban studies discuss the extensive building of skyscrapers and malls in relation to economic growth, especially in the foremost global cities of the developed world, such as New York, Tokyo and Washington DC (Sassen: 1991). However, there is a scarcity of empirical studies investigating the degree to which non-Western and developing countries and cities take part to this global urban transformation (Deboulet, Berry-Chikhaoui, Roulleau-Berger: 2007). This article proposes to redress the balance by taking the example of Nouakchott in Mauritania and Khartoum in Sudan, as emerging capital cities under the impact of globalization.

In the Arab world, one of its manifestations is the widespreading of prestige urban projects, inspired by the Gulf models, especially Dubai (Barthel, Verdeil, 2008; Barthel, 2008). This paper discusses how urban projects in Khartoum and Nouakchott take inspiration from this hypermodern and fascinating urbanism (Schmidt: 2006, Lavergne: 2009, Elshatshawy, 2010). Like many cities of the Maghreb and the Middle East (Elshatshawy, 2006; 2008), Nouakchott and Khartoum are undergoing massive urban transformations characterized by the construction of new residential areas and central business districts. Qatar, Kuwaiti or Saudi companies finance them. Previously, these cities did not attract significant global capital due to the fact that they were located between the Arab world and Sub-Saharan Africa. Even if they were unexpected, contemporary modernizing urban settings and financial over-investments in real estate show how they are entirely involved in globalization.

These projects represent a strategy to trace a proper pathway to hyper-modernity emerging from geopolitical marginality on the international scene. New economic and financial opportunities, such as oil exploitation inflows, offer the chance to give these cities an image of successful development. Notwithstanding, this prestige urban by chronic econos by cholic: the manic povety that fic the Khartoum can be considered African cities.

Relying on long-term fieldwork in Khartoum and Nouakchottit, the article employs a comparative approach in order to expose the common urban dynamics resonating with the emergent model of "Dubaisation". We will first demonstrate how the genesis of these urban projects is intricately linked to the discovery of oil and foreign investments. An in-depth analysis of the main urban projects will prove that the State, as the primary landowner, takes part actively in this privatization process with new neoliberal policies. Then, the article will focus on conflicting issues arising within the local society, such as people displacement and claims to land, illustrating the side-effects of urban transformations in various popular neighbourhoods. Finally, this paper highlights the flagrant discrepancy between such luxurious, ostentatious and extravagant projects and the harsh realities within urban and national settings heavily characterized by poverty.

\section{Urban projects pouring out of oil holes}

A wind of change has been blowing through Nouakchott and Khartoum since their integration into the petro-countries circle. This has generated a two-tier process: these capital-cities have become new eldorados for foreigner investors, and they follow the path of Emirates' development.

In Khartoum, new office towers, stores, malls, lush golf courses and gated communities are rapidly sprouting on the banks of the Nile as well as within the wealthy districts. The image of downtown Khartoum is one of a vast construction site. The suburban areas are no less untouched by the construction of luxurious compounds. The airport, currently located at the heart of Khartoum, is due to be relocated from the downtown area towards the south-western fringe of the city. All of these physical transformations inscribed on the face of the city epitomize the new economic wealth of Sudan. Heralded by the discovery of crude oil, the growth is one of the fastest of the world in the last decade. In Sudan, the tentative oil production levels of August 1999 have seen a significant increase and today the country prides itself on the production of 500000 barrels of crude oil per day. The economic growth of the country has been 500000 barrels of crude oil per day. The economic growth of the country has been exponental reaching a high of oil wealth has not effec regions of the country which have prevalled since independence. On the contrary they have renforced

The oilfields that had been discovered in the 1970's in the southern region of the
conomic sustenance (Denis, 2005). country are at present overwhelmingly in the hands of foreign companies, especially those from East Asia. In a matter of a few years, East Asia has become the primary commercial partner of Sudan with $80 \%$ of exportation directed towards this region of the world and $34 \%$ of imports emanating from it. These foreign companies, generally Chinese (CNCP), control the oil industry and penetrate the whole of the Sudanese economy. Despite the influence of these companies, they are not the only presence on the Sudanese landscape. Other investment includes Arab and European capital. The latter interest has been ignited by a favourable economic climate that has been enhanced by the signing of the peace agreement between the Sudanese state and the SPLA (in the south) bringing an end to a protracted civil war ${ }^{\text {iit }}$. 
Capital cities appear as entry points where the power and influence of the new class of global actors are clearly on display. A class of Sudanese, Arab and Asian businessmen has emerged thanks to petro-dollar inflows. The building called "Burj alFatih", with its sail outline that evokes the "Burj al-Arab" in Dubai, embodies this Sudanese change. The construction and real estate sector remain the most solid forms of investment adapted to the nature of a political economy based on patronage. Hence, petro-dollars continue to be reinvested in this sector within Greater Khartoum. This newly developed business class purchases and builds hotels, resorts, high rise villas... taking advantage of an increasing western humanitarian presence that contends with the fragile peace process and a full blown crisis in the Darfur region (Bartoli, 2006). These Simultaneously, they are making the construction sector more dynamic.

The discovery of oil has provided the Sudanese government with millions of dollars in disco. This of dollar ine discogram rather and the White Niles. Between 2005 and 2009, three more bridges confluence of the Blue and he whe Currently, the edifcation of a binge is underway to comnect Khantorn to the new airpor. The frenzied development sector. Road construction ties to follow the lange ince pase of private vehicles that furthest outskirts of the city.

In juxtaposition, Mauritania has followed a similar path in recent years. In July 2009, Mauritanians watched on the internet a video clip of the soon to be elected presidential candidate Mohammed Ould Abdel Aziz. "The constructive change" video showed plans for a new modern city, dotted with skyscrapers, malls, pipelines, and luxury resorts. A running water tap symbolized the victory of Aziz-driven developmen on the desert. Although this virtual video still seems a mirage, Mauritanians were swayed to conceive of it as reality due to the announcement of oil exploitation that proclaimed economic development, success, and opulence. In 2001, the Australian oil company Woodside had discovered untapped supplies and has been exploiting them since 2006, fostering hopes of Mauritania becoming a new "Oil Emirate". In late 2007, after an embezzlement scandal, Woodside sold its operating licence to the Malaysian giant oil company, Petronas. Various oil companies were granted new oilfields discovered within the onshore Taoudenni area: Total (France), Repsol (Spain) and CNPC (China). The experts estimated the potential reserves at 400 million barrels of crude oil: Mauritania could become one of the ten largest African producers. Actually, the daily extraction, initially estimated at 75,000 barrels, is a mere 15,000 barrels.

This recent discovery of oil heralds a new phase of economic growth. It equally signals a political change. after being discredite recognition on the international stage and to attract foreign funds. During a meting in 2008 between the former Maritanian President Sidi Ould Cheikh Abdallahi, Qatars

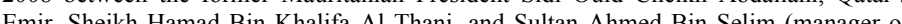

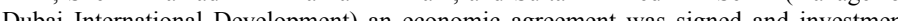
opportunities were evaluated. These evaluations significantly focused on the banking, energy, tourism, mining, and urban sectors. Nowadays, this economic transition is materially visible: the first historical colonial buildings located downtown were destroyed leaving room for a new central business district. The town council planned to build five skyscrapers. One of them will be the "Oil tower". The Libyans are constructing a 30storey hotel. Kuwaiti businessmen have planned to build yet another in the north of the city. Gulf companies promoting urban development have their headquarters in new luxury buildings like the "Al-Khaïma City Centre", the new luxury shopping mall erected in Nouakchott downtown. The Qatari Diar Real Estate Company is promoting a one million dollar luxurious resort twenty kilometres North of the capital. This project is called "Nouakchott new town". Even if the financial investment is lower in Mauritania than in other countries such as Sudan or Morocco (See Barthel, Planel, in this issue), it is comparatively important for one of the poorest and underdeveloped country lacking in significant private investments Nounchott, the former Mauritanian foreign minister the representative of Diar Qatari in "Now Mauritania is the place to be. It is remote from the main Arab centres. The Qatar Sudan and the Comoros Islands that are not very inflential. but which have the

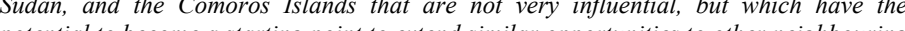

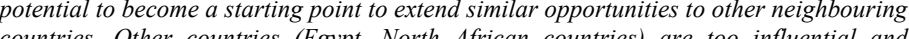
countries. Other countries (Egypt, North African countries) are too influential and
complicated $^{\text {,iv }}$.

Nowadays, these capital cities are attractive to foreigner investors, thanks to neoliberal policies and strategic political alliances. They benefit from the increase in revenues accrued from land tenure, and the transformation of petro-income into real estate projects. The State is not only encouraging them to invest, it is involved in these projects as one of the main actors of the urban metamorphoses.

\section{Is the Capital city up for sale?}

In the neo-liberal economic climate, the execution of prestige projects is accompanied by a certain number of conflicts pitting small-scale landowners, the State and important investors against each other. Segments of the city are for sale or reclaimed in order to concede a place for these colossal programmes. Thus, it is worth posing the salient question "is the Capital city for sale?" (Bredeloup, Bertoncello, Lombard, 2008). Unmistakably, the main actor of this privatization is the State. Since in such instances the State is the main landowner, the new context of speculation has serious implications for urban policies and priorities in urban planning.

In Khartoum, the transformations of the Ministry of Urban Planning give evidence to the fluctuations and evolutions of the revenues accrued from urban property and land. In 1996, Johan Post indicated that the budget reserved for the construction of urban structures was extremely low. In addition, the fiscal prowess of the Ministry of Urban Planning was significantly weak. At that time, the Ministry was housed within a humble run down building, seriously lacking in material resources (Post, 1996). This description stands in stark opposition to the imposing buildings at the heart of the city that the 
Ministry of Urban Planning occupies now. In 2005, the Ministry was well equipped with a state of the art Department of Cartography directed by highly qualified personnel.

The increasing interest of the State in land tenure creates novel forms of publicprivate partnerships. In 2004, the Governorate of Khartoum and the Ministry of Physical Planning and the National Social Insurance Fund signed a partnership agreement with Dal Property Development, one of the most powerful Sudanese private companies ${ }^{v}$. The aim of the agreement was to establish the Alsunut Development Company. This publicprivate partnership was convened to reactivate an "area of business prosperity" in the AlMogran zone - the confluence of the Blue and White Nile Rivers. This \$4 billion development project consists of two main phases: the first comprising the construction of a Central Business District (CBD) and the second a residential estate portion. Completion is expected by 2014 with 630 hectares of office space, 1100 villas, 6700 apprtments affording living space for 40000 residents and visitors, a marina and a golf course. The site is expected to generate jobs for 50000 employees (http:/www alsunuts. The site is expected to ger Sudanese government clarifies in its website th " "his ste-of-he-art, prime co

On the opposite bank of the Nile within the Abu Se'id area, another waterfront project "Medinat al-Noor" is under construction (http://ipc-kwt.com/al-noor.html). The urban structures remind of the Al-Mogran project: shopping malls, office blocks, high rise accommodation (communal buildings as well as individually owned villas), a zoo and a golf course. The zoo and the golf course equally feature in the Alsunut project mentioned above. The magnitude of "Medinat al-Noor" is such that an industral zone has been envisaged as part of the project. Furthermore a certain quantity of space has been reserved for a police station as illustrated by 3D images.

Land destined for sale is most often situated on the banks of the Nile and animated with its history. This is land that has been appropriated by those who have occupied it over a long duration of time and furthermore bears the marks of their identities and social biographies. Over the years farmers had cultivated the greates expanse of this area only to find that their agricultural land was now being transformed into land reserved for construction. This is evident at the confluence of the Blue and White Niles where investors are intending to transform the face of Tuti Island, a rura haven of peace. The private Tuti Island Investment company, which has undertaken this urban development project, appraised at five billion dollars ${ }^{\mathrm{vi}}$, exhibits its impressive visual images and videos on the Internet (http://www.tuti-island.com/media.html) (Fig. 5). The company has close links with China and Egypt who guide the master plan with an engineering firm from Kuwait and a Malaysian subsidiary that execute the work. Before the erection of a modern suspension bridge (at a cost of 14-million dollars), achieved in 2009 , access to the island was limited and dependant on the water ferries that crossed the river. The island had been a primary example of uncustomary and successful resistance to the thrust and pressure of urbanisation (Lobban, 1982). However, this resistance was curtailed by the desire of government planners and private businessmen to link the island to the other segments of the city via bridges (Omdurman and Khatoum North) in order to allevite recuring traffic jams. In this way, they envisaged to both business district.
Fig. 1: Main real estate projects in Greater Khartoum

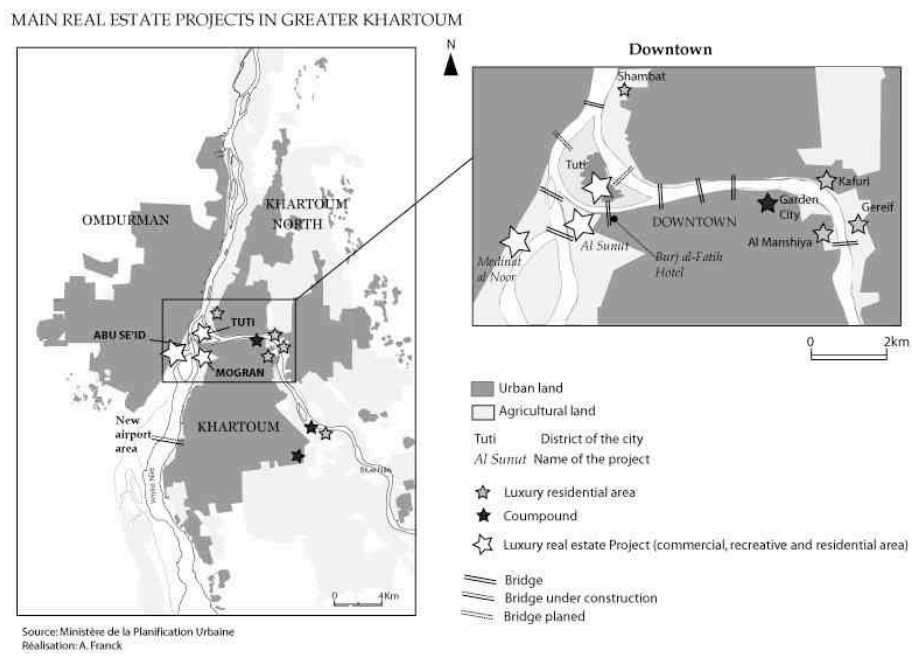

On a different part of the continent, in Mauritania, we can similarly observe how private or public interests motivate investment choices. For the Mauritanian State, it has been relatively easy to sell the land on the outskirts of Nouakchott. Created ex-nihilo in 1960 , the new capital city is surrounded by uninhabited sand dunes. There is no physical obstacle to urban sprawl... and speculation. In 1983, a law enacted the end of tribal rights in land tenure. The State became the landowner and a real estate investor and a property developer for luxury projects. A primary example of this phenomenon is the Socogim ${ }^{\text {vii }}$, the national society of building and real estate, created in 1974. In the 1970's, during the urban growth caused by the droughts, the role of the Socogim was to construct urgently needed social houses. At present, it is promoting a high-rise housing estate composed of 400 villas, named « Socogim beach », for the most solvent clients of the most influential banks (Choplin, 2009). Obviously, social housing projects are not any more the priority of authorities.

In addition, when the State is not directly the property developer (Socogim case), it is promoting private investments with new legislation. In 2005, a law recognized officially the property developer profession. Since then, companies offer investments and $\mathrm{FCI}$ is one of those societies, proposing investment funds, via its real estate subsidiary 
"I'mar". This company attempts to follow the Islamic financial principles, extremely popular within the Arabian Peninsula, promoting an "Islamic" quarter in the suburbs of Nouakchott. The future quarter, called "Sukuk", is visible on the website (http://www.imar.mr): 50 villas, 60 allotments, and a central plot of $4650 \mathrm{~m}^{2}$ to become a central business district. The naming of this suburb connotes the diffusion of Islamic financial principles largely guided by those of the Middle East. The sukuk investmen funds, developed by I'mar Company, are structured in compliance with Islamic law ${ }^{\text {vil }}$. The sale of sukuk (Arabic plural. "title") is primarily directed at Islamic investors who are prohibited by Shari'a law from investing in conventional debt securities. Under these terms there is no risk of usury or earning interest on money loaning. As Ould Bah and Ould Cheikh (2009) write, even in Mauritania "the pious local economy is increasingly connected to the vast network of the Islamic globalized finance". The sukuk exsingly connected to demonstes are not only produced by foreign investments but by a subtle blending of the chnes a the different in

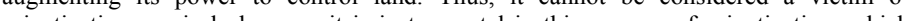

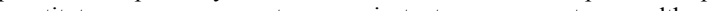

Fig. 2: Socogim Beach, Nouakchot

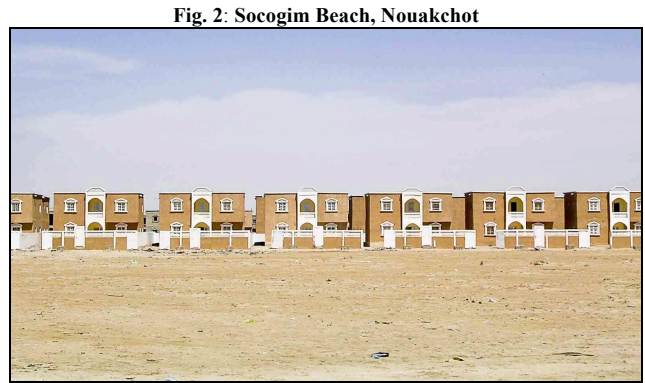

C A. Choplin, Janvier 2008
Figure 3 : Main real estate projects in Nouakchot

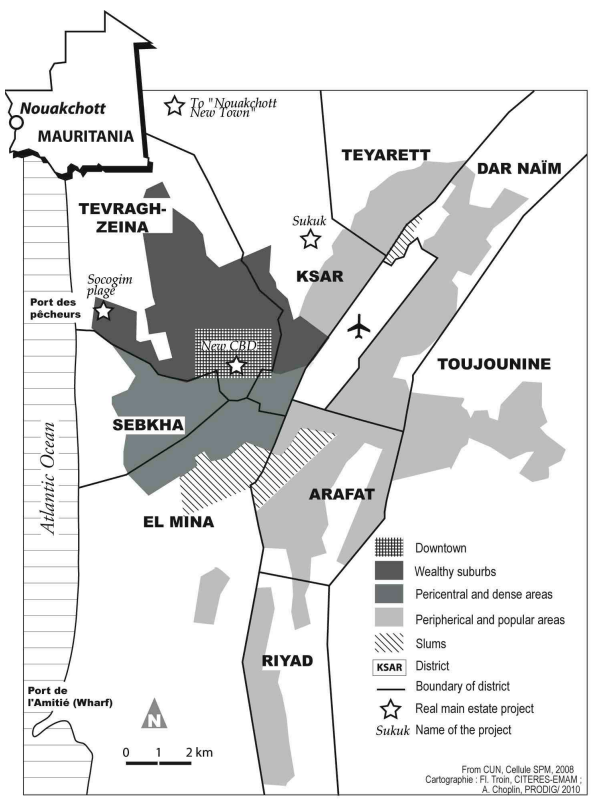


Fig. 4: "Sukuk" Project, in the sandy outskirts of Nouakchott

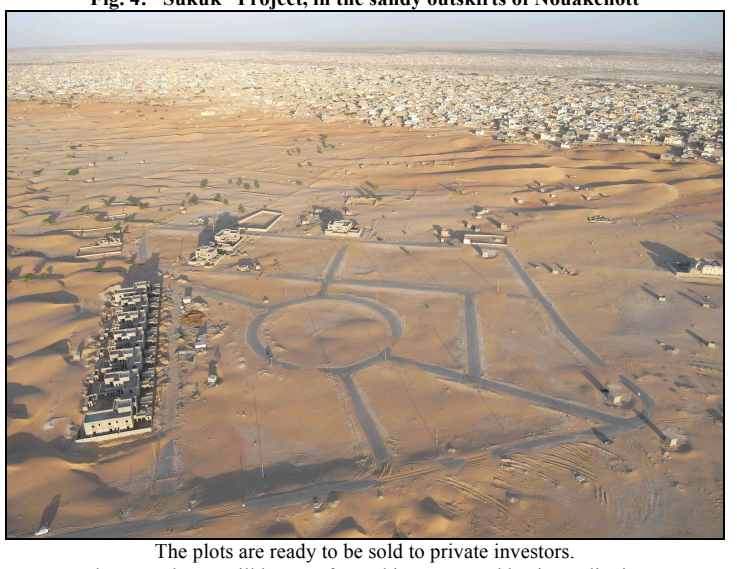

The central area will be transformed into a central business district.

http://www.mauritanie-decouverte.net/nouakchott vue du ciel/index.htm

However, in December 2009, three years after the project's inception, only seven houses have been built. Whereas the Sukuk northern suburb is awaiting the demand of buyers, the Qatari program "Nouakchott new town" seems to be on hold. In November 2009, the Diar Mauritanian representative was awaiting a delegation. He stated: "The project will go on. We have been delayed because of the last coup d'état. With the lates political unrest, water and electricity networks remain unconnected. But, the master plan (realized by the French society Vinci) has been passed". In response to our query about the possibility of the project coming to a halt due to the international financial crisis, he answered: "the project has not been interrupted but has been revised proceeding from bottom-up. First we will focus on the five star hotel (200 000 \$US)." Despite such "Despite such reassite with the Diar Kh be whett an "Whest that present hey remin on in an agreements do not always culminate in tangible achieved projects.
Figure 5: comparative table of projects in both cities

\begin{tabular}{|c|c|c|c|c|c|c|}
\hline & \multicolumn{3}{|c|}{ KHARTOUM } & \multicolumn{3}{|c|}{ NOUAKCHOTT } \\
\hline & Al Mogran & $\begin{array}{c}\text { Medinat al- } \\
\text { Nour }\end{array}$ & Tuti & $\begin{array}{c}\text { Socogim } \\
\text { plage }\end{array}$ & Diar & Sukuk \\
\hline Developers & $\begin{array}{c}\text { Alsunut } \\
\text { development } \\
\text { company }\end{array}$ & $\begin{array}{l}\text { Medinat al- } \\
\text { Noor company }\end{array}$ & $\begin{array}{c}\text { Tuti Island } \\
\text { Investment } \\
\text { private } \\
\text { company }\end{array}$ & SOCOGIM & Diar company & $\begin{array}{c}\text { I'mar } \\
\text { company }\end{array}$ \\
\hline Investment & 4 billion $\$$ & 7 billion $\$$ & 5 billion $\$$ & 12 million $\$$ & 1 million $\$$ & 3 millions \$ \\
\hline $\begin{array}{l}\text { Main } \\
\text { partnerships }\end{array}$ & $\begin{array}{c}\text { PPP: } \\
\text { DAL Co., } \\
\text { Khartoum State } \\
\text { and the National } \\
\text { Social Insurance } \\
\text { Fund }\end{array}$ & $\begin{array}{c}\text { PPP: } \\
\text { Grand Real } \\
\text { estate company } \\
\text { and Khartoum } \\
\text { State }\end{array}$ & $\begin{array}{c}\text { Private } \\
\text { investments }\end{array}$ & $\begin{array}{c}\text { PPP: } \\
\text { Public real } \\
\text { estate } \\
\text { program }+ \\
\text { banks } \\
\text { agreements }\end{array}$ & $\begin{array}{c}\begin{array}{c}\text { Private } \\
\text { investments }\end{array} \\
\end{array}$ & $\begin{array}{c}\text { PPP: } \\
\text { FCI } \\
\text { company, } \\
\text { Maurtianian } \\
\text { state, } \\
\text { Shelter } \\
\text { Afrique } \\
\text { (international } \\
\text { real estate } \\
\text { investor) } \\
\end{array}$ \\
\hline $\begin{array}{l}\text { Type of } \\
\text { projects }\end{array}$ & $\begin{array}{l}\text { Economic, } \\
\text { commercial, } \\
\text { residential and } \\
\text { leisure resort }\end{array}$ & $\begin{array}{l}\text { Economic, } \\
\text { commercial, } \\
\text { residential and } \\
\text { leisure resort }\end{array}$ & $\begin{array}{l}\text { Economic, } \\
\text { commercial, } \\
\text { residential and } \\
\text { leisure resort }\end{array}$ & $\begin{array}{c}\text { Residential } \\
\text { project }\end{array}$ & $\begin{array}{l}\text { Economic, } \\
\text { commercial, } \\
\text { residential and } \\
\text { leisure resort }\end{array}$ & $\begin{array}{c}\begin{array}{c}\text { Economic } \\
\text { and } \\
\text { residential } \\
\text { resort }\end{array} \\
\end{array}$ \\
\hline $\begin{array}{l}\text { Origins of } \\
\text { contractors }\end{array}$ & $\begin{array}{c}\text { Dubai, Abu } \\
\text { Dhabi, Malaysia }\end{array}$ & Koweit, Egypt, & $\begin{array}{l}\text { Sudan, Egypt, } \\
\text { Koweit, } \\
\text { Malaysia, China }\end{array}$ & Mauritanian & Qatari & Mauritanian \\
\hline $\begin{array}{l}\text { Infra } \\
\text { structures }\end{array}$ & $\begin{array}{c}\text { a central } \\
\text { business district, } \\
1100 \text { villas, } 6 \\
700 \text { apartments, } \\
\text { a marina and a } \\
\text { golf course }\end{array}$ & $\begin{array}{c}120000000 \mathrm{~m}^{2} \\
\text { Shopping malls, } \\
\text { office blocks, } \\
\text { high rise } \\
\text { accommodation, } \\
\text { a zoo and a golf } \\
\text { course }\end{array}$ & $\begin{array}{c}\text { Residential } \\
\text { Road networks }\end{array}$ & $\begin{array}{c}400 \text { villas } \\
\text { high-standing }\end{array}$ & $\begin{array}{l}\text { A } 5 \text { star hotel, } \\
\text { and luxurious } \\
\text { villas }\end{array}$ & $\begin{array}{l}50 \text { villas, } 60 \\
\text { allotments, } \\
\text { a central } \\
\text { business } \\
\text { district }\end{array}$ \\
\hline Websites & $\frac{\underline{\text { http: }: / \text { www.alsu }}}{\text { nut.sd/ }}$ & 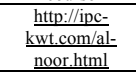 & $\begin{array}{l}\frac{\text { http://www.tuti- }}{\text { island.com/medi }} \\
\text { a.html }\end{array}$ & $\begin{array}{c}\text { http://www.so } \\
\text { cogim.mr/acc } \\
\text { ueil.htm }\end{array}$ & $\begin{array}{l}\text { http://www.qa } \\
\text { taridiar.com } /\end{array}$ & $\frac{\underline{\text { htpp://www.i }}}{\underline{\underline{\text { mar.mr. }}}}$ \\
\hline
\end{tabular}

It is noteworthy that these "turnkey projects" follow international principles, deploying Anglo-Saxon terminology (expert, benchmarking, master plan, workshops, waterfront...), inspired from managerial and consulting processes (Barthel, 2008; Barthel, Verdeil, 2008). At the same time, companies are trying to adapt these international tools to local contexts. For instance, architectural styles evoke Arab cultural and historical influences and the project names are often Arabic signifiers (Al-Khaïma center refers to the nomadic tent; Burj al-Fatih takes on the name of Qadhafi's revolution in 1969...). Indeed, some urban areas seem to be transposed segments of Dubai, complying with international standards. The international standards are embodied in the use of videos, websites and futuristic images as marketing props. Gaining access to these master plans and internet sites, that portray an ideal and simplistic picture of these iconically pharaonic projects, conceptor the project manement and the contracting owner, turns out to be a more delicate undertaking. The various actors are really reticent to divulge such information. 


\section{To whom does the city belong?}

This use (and abuse) of marketing tools invite us to go beyond the simple images and basic rhetoric in order to analyse the side effects on local context and populations. Gazing upon the advertising spots depicting the "urban future", one might venture to ask to whom exactly is this city destined? For whom are these extravagant spaces provided? Arab investors? Local inhabitants? Moreover, we speculate why the central government and private investors desire to beautify and upgrade the cityscape when the majority of its inhabitants remain impoverished and in need of low-income housing projects. The obvious response would suggest that the priorities of citizens are not taken into account in this lifestyle vision of luxury and entertainment. Therefore, such advertising strategies stand in stark contrast with the needs and realities imposed by the national context. In Mauritania, any proclaimed steps towards modernity and prosperity are unfortunately taking a long time to bear the fruit of improving the everyday living conditions of normal citizens (Choplin 2010). Indeed, the political video used by the new president during the last elections seems to be excessively extravagant, exaggerated and unrealistic. For the larger majority of Mauritanians and Sudanese, the promise of globalization gives rise to heightened frustration since it appears to be more symbolic than real. These expectation create a kind of apprehencion and the some time a huge desire to participecte in this phes a the new urban projects are characterized by The naradox and the other hand, modernity and hope.

Moreover, the increase in competition over urban projects has sparked local conflicts over land possession. In Sudan, this phenomena is marked by a brand new building bearing the sign "Administration for conflict resolution". Indeed, the fact that most of the projects are being erected on agricultural lands has changed the legal classification of the plots being exploited". This engenders conflicts surrounding their appropriation. In 2001, while the restriction of agricultural activity at Mogran did no trigger off an important revolt, we met some farmers, angry yet powerless to claim the right to stay on their land (Franck, 2007). In contrast, in January 2009, the project envisaged as Medinat al Noor elicited the first expletive outcry related to the use of land. The national newspaper al-Watan consecrates two of its cover stories to this topic ${ }^{\mathrm{x}}$. The fact that valuable land is being transformed into a construction site would provoke the discontent of the owners with the decisions taken by the State of Khartoum to reclaim this land. The evicted owners would rise up in particular against the manner in which the authorities were meeting their target by selling the plots to a Kuwaiti company. They have authorised the beginning of construction work before ensuring that the previous owners have been compensated as well as neglecting to ensure that grievances taken to court have been addressed. In order to be audible and visible, the previous owners physically occupy the land already under construction. They vocalised their complaints by stating that they had neither been accorded adequate notice of their eviction nor been compensated before the actual sale of the land they occupied in 2006. They quoted that both elements were clearly stipulated by law and thus such behaviour was in direc contradiction to the legal frameworks of the State. This complaint was reverberated outside the confines of the $A b u$ Se'id area and markedly implicated land owners from the south west of the capital until Jebel Aulia affected by both this project and that of the construction of the new airport.

Thus, step-by-step, in Khartoum, the political and business elite have designed a closed city, characterized by landscaped buffers, gated communities and residential enclaves, as is clearly demonstrated in the Al-Mogran project (Crombé, 2009). Whatever the intent, such choices have indirectly created a security belt that is taking form by isolating the urban air-conditioned elite and the lower strata of society from each other. These urban and political choices wilfully encourage fragmentation: the centre is no longer characterized by a shared public place but has become a place to be shared, between those having private interests. Accordingly, this globalization process is limited to selected spaces as well as people. In exclusively targeting the affluent, such projects to selected to the as "just city", characterized by "material equality, diversity and democracy" (Fainstein, 2009; city", ch 2009, Har "2009). Esentilly bas on Macuse, 200. He " what is (he "beautiful inority.

From a different vantage point, these ambitious projects are equally vulnerable to the risk of being non-financially viable. Clearly, for the large majority of the local population the purchase of luxurious apartments is marked by superfluity. The volume of the local elite and the expatriate community is insufficient to cover the capital expenditure. The threshold of profitability is very high. Moreover, the effectiveness and feasibility become all the more pertinent. For instance, one might exercise a certain amount of scepticism regarding the master plans for Tuti Island. The three proposed plans completely disregard both the historical record of the island pertaining to land use as well as its uses in the very recent past. In the video imagery, the village has been obliterated, and the agricultural plots of land (still distributed in terms of irrigation units) are invisible. We are neither provided with the information explaining how the totality of this land is subject to complex rules of fragmentation directly guided by the precepts of Islamic inheritance law. Nor is it clarified that the complexity of this law accounts for a multitude of landowners on the island. By being presented in a sanitized and unproblematic process through the visual media, these projects seem to lose any authentic connection to the realities, characterized by land use micro-politics, cultural and financial stakes. Hence they become entirely deterritorialised virtual images standing outside the time and place they purport to represent. 


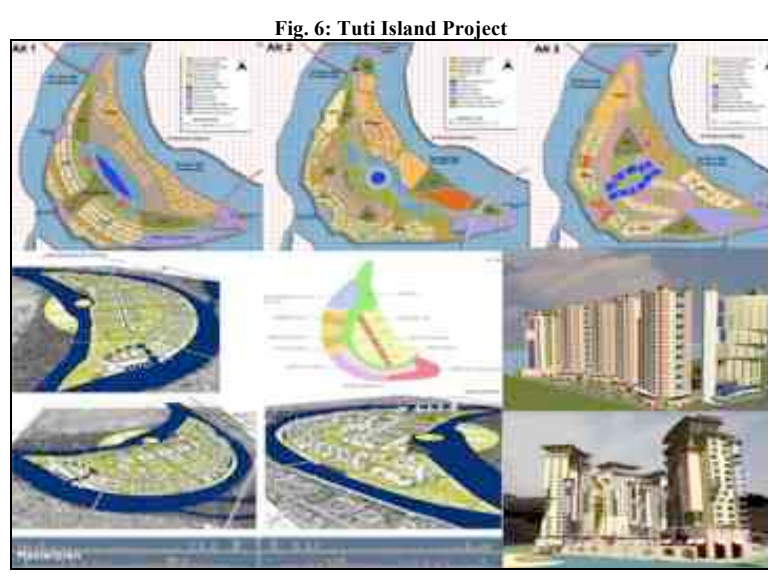

Source : (http://www.tuti-island.com/media.html).

In each pattern, the village is relocated, as if it was a simple infrastructure.

Faced with these images, it is pertinent to question the future prospects of these urban modern clusters and the fate of the city in general. While such urban projects
clearly target the affluent members of the local society, this does not eliminate the possibility that the city dwellers might take it upon themselves to appropriate these possibility that the city dwellers might take it upon themselves to appropriate these
prestigious areas. For instance, in Khartoum, in largely unanticipated ways, the upmarket shopping many citizens, including modest and poor ones. This idea is also valid for a trendy cafe constricted in ins certainly inspired a vogue that makes use of structures in the urban landscape as meeting points, spaces to have picnics and to consume Coca-cola... Similarly in Nouakchott, while the completion of the sukuk project is awaited, the local population takes advantage of this electrified area. Hence, it makes use of this empty space in the evenings to play cards or have tea underneath lighting provided by street lamps.

In less than ten years, the faces of Khartoum and Nouakchott have changed due to the injection of billion dollar construction projects. Therefore, the oil discovery and globalization has provoked a spatial reversal: Sudan and Mauritania's marginal positions have become an advantage. Obviously, such new strategic geo-political situation and connections entail important spatial and identity changes. Thanks to these two examples, we note how the capital city has become the showcase of internationalisation, a tool for attracting capital flow and for generating new inward investments and speculation on land tenure (Berry-Chikhaoui, Deboulet, Roulleau-Berger, 2007). As the envisioned future morphologies of Nouakchott and Khartoum illustrate, these cities are striving to be competitive spaces in the globalizing economy ${ }^{\mathrm{xi}}$. The modernity embodied in the Emirates states appears as the exclusive path towards modernisation. In spite of the differences - between the two countries - in policies, projects, the amount of money invested and the stage of the process (more advanced in Sudan), both are enduring the same influences.

At present, both Nouakchott and Khartoum are looking forward to a future that may appear ephemeral. The comparison with Dubai as the quintessential post-petroleum city (Lavergne, 2009) stops short. In 2010, the Dubai urban-financial system has collapsed, echoing the transient nature of such projects. In light of the current global economic uncertainty, the potential investors and private firms could firstly withdraw from the margins of the Arab world. Recently strategic, this marginal position can become a cause of instability and fragility. Moreover, facing political and social unrest and poverty, it is increasingly difficult to believe in the feasibility of such prestige urban
projects and in the possibility of their full achievement. Some of them, as Sukuk and projects and in the possibility of their full achievement. Some of them, as Sukuk an

Barthel P.-A. (2008) Faire du grand projet au Maghreb. Géocarrefour, Varia, n83/1, pp. 25-34 Barthel P-A, Verdeil E. (2008) Experts embarqués dans le « tournant financier » : le cas des grands projets urbains au sud de la Méditerranée. Annales de la recherche urbaine, $n^{\circ} 104$, pp. 38-48

Bartoli S. (2006) Khartoum et l humanitaire : une approche spatiale de l'implantation des agences internationales. Master 1 thesis in geography, Univ. Paris 1-ENS Lyon, $124 \mathrm{p}$

Berry-Chikhaoui Isabelle, Deboulet Agnès (ed.) (2000) Les compétences des citadins dans le monde arab

entre tensions et réactions des habitants. Paris, La Découverte, 325 p. La privatisation made in Africa des services urbains. Paris : L'Harmattan, $354 \mathrm{p}$.

Choplin A. (2006) Fabriquer des villes-capitales entre monde arabe et Afrique noire: Nouakchott (Mauritanie) et Khartoum (Soudan), étude comparée. PhD thesis in geography, Univ. Paris-1 Panthéon-

(2009) Nouakchott au carrefour de la Mauritanie et du monde. Paris : Karthala-Prodig,

Choplin A. (Forthcoming in 2010) From the Chingetti mosque to Dubai towers. Extraversion, connection,

and neo-urban society in a globalized Mauritania. The Maghreb Review " ?", EspacesTemps.net,
Crombé L. (2009) "« Building Khartoum's future " http://espacestemps.net/document7752.html
Denis E. (2005) Khartoum, ville refuge et mét

Villes (205) Khartoum, ville refuge et métropole rentière, Mégapolisation des crises VS métropolite.

Elsheshtawy, Y. (2006), "From Dubai to Cairo: Competing Global Cities, Models, and Shifting Centers of
Influence?" In P. Ammar \& D Singermun (eds). Cairo Cosmopolitan: Politics, Culture, and Space in the New Middle East. Cairo: American University in Cairo Press

Elsheshtawy Yasser (ed.) (2008), The Evolving Arab City. Tradition, Modernity and Urban Development. London: Routledge, 314

Elsheshtawy (2010) Dubai: Behind an urban spectacle, London; New York: Routledge, $294 \mathrm{p}$.
Fainstein S. (2009) Spatial Justice and Planning. justice spatiale | spatial justice | $\mathrm{n}^{\circ} 01$ | http://www.jssj.org 
Franck A. (2007) Produire pour la ville, produire la ville : étude de l'intégration des activités agricoles el des agriculteurs dans l'agglomération du grand Khartoum. PhD thesis in geography, Univ. Paris X Nanterre, $508 \mathrm{p}$.
Harvey David (2009) Social Justice and the City. University of Georgia Press, $368 \mathrm{p}$.

Lavergne M. (2009) Dubaï, utile ou futile ? Portrait d'une ville rêvée à l'heure de la crise. Hérodote, no 133 , pp. 32-57.

Lobban r. (1982) Class and kinship in Sudanese urban communities. Journal of the International African Institute, Vol. 52, n० 2, pp. 51-76.

Marcuse P. et al., eds. (2009) Searching for the Just City. New York, London: Routledge, 264 p.

Ould Ban M.F., Ould Cheikh A.W. (2009) "Entrepreneurs moraux et réseaux financiers islamiques en 137. (1996) The politics of aban plonning in the Sudan. Habitat International, vol. 20, no 1 , pp. 121 137. Sassen Saskia (1991) The global city: New York, London, Tokyo. Princeton: Princeton university press, 397
p.
Schmidt H. (2006) Economy of Fascination :Dubai and Las Vegas as examples of themed urban landscapes. Erdkunde, vol. 60, 2006, pp. 346-361.

${ }^{i}$ We are grateful to Marc Lavergne, Sabine Planel, Riccardo Ciavolella and the anonymous reviewers for their helpful comments on earlier drafts of this paper. We wish to thank Azza Yacoub and Jennifer Barak

for the translation.
ii The article is based on research evidence collected during long-lasting fieldworks in Sudan and
Mauritania. A. Franck carried out a 4 years fieldwork in Sudan between 2001 and 2005 for her PhD (Franck, 2007) and again in 2009. A. Choplin's fieldwork experience in Sudan consists of two field research in 2006) and 2005, and or regular fleldworks in Mautitania (20 monhs), from 2000 to the present (Choplin, 2006). This article relies on data gathered during interviews with companies' managers, civi iii In January 2005, a Comprehensive Peace Agron

of Khartoum and the Sudan People's Liberation Movement (CPA) was signed between the central governmen independence of the South. As specified in the CPA, the Southern Sudanese have the right to decide whether Southern Sudan will become an independent nation or whether it will remain part of a unified Sudan in January 2011 .

"Interview, Nouakchott, 22/01/2009

The DAL Group consists of independent companies operating in the consumer, industrial, agricultural an Coce Colo, and represent Mitsubishi group, Caterpillar " Khartoum investors eye Tuti Island», Middle East Online, 2008-03-24, http://www.middle-eastonline.com/english/?id=25011

Socogim: Société nation

viii See «Finance islamique : les Sukuk gagnent du terrain », La tribune nº16, 20/09/08 ; « Interview M.

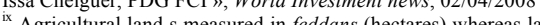

and reserved for construction is measured in Ituralists is derisory in relation to the value of x "The matter of compensation following the reclamation of the sawagui of Abu Se'id" Al-Watan, $23^{\prime \prime}$ January 2009. "Land owners of Abu Se'id lay siege to the construction site of Medinat al Noor" $\mathrm{Al}$ Watan, $3^{3}$ February 2009

prese pridents, Mohamed Ould Abdel Azziz and Omar AlBecer 2009. They planned to reinforce the economic cooperation- 